Studia nad Autorytaryzmem i Totalitaryzmem 42, $\mathrm{nr} 2$

Wrocław 2020

https://doi.org/10.19195/2300-7249.42.2.5

PRZEMYSŁAW MALINOWSKI

ORCID: 0000-0002-4347-7437

Uniwersytet Opolski

p.malinowski@przemyslawmalinowski.pl

\title{
Przedsiębiorstwo państwowe jako podmiot postępowania arbitrażowego w systemie prawnym gospodarki nakazowo- -rozdzielczej końcowego okresu PRL
}

\begin{abstract}
Abstrakt: Niniejsza publikacja traktuje o przedsiębiorstwie państwowym jako jednym z podstawowych podmiotów systemu gospodarki nakazowo-rozdzielczej schyłkowego okresu PRL. Tym samym wskazano na istotę prawnomaterialną przedsiębiorstwa państwowego oraz jego formalne aspekty funkcjonowania w systemie dochodzenia roszczeń w ówczesnym postępowaniu arbitrażowym.

Zarówno samo postępowanie arbitrażowe, jak i funkcjonowanie Państwowego Arbitrażu Gospodarczego jako organu pozasądowego uprawnionego do rozstrzygania i zapobiegania powstawaniu w przyszłości sporów o charakterze gospodarczym było charakterystyczne dla ówczesnego systemu politycznoprawnego.

Co do zasady sama istota rozstrzyganych sporów i ich zakres przedmiotowy odnoszący się do szeroko postrzeganych spraw o charakterze gospodarczym mógłby — przy uwzględnieniu określonych ówczesnych oraz współczesnych realiów - wpasowywać się w nurt szeroko postrzeganego sądownictwa gospodarczego. Niemniej jednak zarówno podmioty postępowania, jak i sam organ rozstrzygający były ściśle związane ze specyfiką prawnoustrojową gospodarki nakazowo-rozdzielczej.

Specyfika ta dotyczyła między innymi działalności prowadzonej przez ówczesne przedsiębiorstwa państwowe. Należy bowiem wskazać, że działalność tychże podmiotów, prowadzona na podstawie wydzielonych na ich potrzeby części mienia ogólnonarodowego, była co do zasady samodzielna pod kątem formalnym, a tym samym w ograniczonym stopniu wykazywała pewne znamiona współcześnie postrzeganej działalności gospodarczej. Jednakże pod kątem materialnym działalność ta była nierozerwalnie podporządkowana realizacji określonych celów i zasad wynikających z narodowych planów społeczno-gospodarczych.

Dlatego też za podstawowe cele jednostek gospodarki uspołecznionej, w tym przedsiębiorstw państwowych, można było uznać nie te związane z samodzielnie prowadzoną działalnością gospodarczą, lecz te, które związane były z realizacją i wdrażaniem centralnie przyjętych zadań państwa, w tym o charakterze gospodarczym.
\end{abstract}


Tym niemniej gospodarka nakazowo-rozdzielcza, mimo wszechobecnego planowania, narzucania i wdrażania zadań oraz środków ich realizacji, nie była wolna od określonych sporów zachodzących miedzy szeroko postrzeganymi jednostkami gospodarki uspołecznionej, w tym między ówczesnymi przedsiębiorstwami państwowymi.

Dlatego też zarówno w celu rozstrzygania tychże sporów, jak i zapobiegania powstawaniu ich w przyszłości został powołany Państwowy Arbitraż Gospodarczy — organ, który na drodze pozasądowej de facto zmonopolizował pod kątem podmiotowym i przedmiotowym zakres spraw gospodarczych rozstrzyganych w ówczesnym systemie prawnym.

Słowa kluczowe: przedsiębiorstwo, przedsiębiorstwo państwowe, arbitraż, państwowy arbitraż gospodarczy, gospodarka nakazowa.

\section{STATE ENTERPRISE AS AN ENTITY IN ARBITRATION PROCEDURE DURING THE DECLINE OF THE PRL'S COMMAND ECONOMY SYSTEM}

Abstract

The present publication refers to the essence of the state enterprise as one of the most essential entities during the decline of the PRL's command economy system. Thereby the legally substantive essence of the state enterprise and formal aspects of its functioning in the vindication of claims system in contemporary arbitration procedure were indicated in this publication.

Both the arbitration proceedings themselves and the functioning of the State Economic Arbitration, as an extra-judicial body, empowered to resolve and prevent future disputes of an economic nature, constituted a certain specificity of the political and legal system of the time.

As a matter of principle, the very essence of the disputes resolved, their material scope relating to broadly regarded cases of an economic nature, could — taking into account certain realities, both then and nowadays - fit into the mainstream of the widely perceived economic judiciary. Nevertheless, both the parties to the proceedings and the awarding authority itself were closely linked to the legal and political specificities of the command-and-quota economy.

These specificities concerned, inter alia, the activity carried out by then state-owned companies.

It should be pointed out that the activity of these entities, carried out on the basis of a part of the national property assigned to them for their needs, was in principle - from a formal point of view independent, and thus, to a limited extent, demonstrated certain characteristics of the business activity as perceived at present. However, from a substantial point of view, this activity was inextricably subordinated to the achievement of specific objectives and principles stemming from national socio-economic plans.

Therefore, the basic objectives of entities conducting their activity within the framework of the planned economy, including state-owned enterprises, could be considered not those related to independently conducted economic activity, but those related to the pursuit and implementation of centrally adopted state tasks, including those of an economic nature.

Nevertheless, the command-and-quota economy, despite the ubiquitous planning, imposition and implementation of tasks, as well as the related means of their pursuit, was not free from certain disputes between the widely perceived entities conducting their activity within the framework of the planned economy, including the then state-owned enterprises.

Therefore, in order to settle these disputes and, what is important, to prevent them from arising in the future, the State Economic Arbitration was established, an authority which, in an extra-judicial manner, de facto monopolized the scope of economic cases resolved in the legal system of that time, both in terms of object and subject matter.

Keywords: enterprise, state enterprise, arbitration, state economic arbitration, command economy.

Studia nad Autorytaryzmem i Totalitaryzmem 42, nr 2, 2020

(C) for this edition by CNS 


\section{Wstęp}

W systemie gospodarki nakazowo-rozdzielczej przedsiębiorstwa państwowe były jedną z najważniejszych (o ile nie najważniejszą) form organizacyjnoprawnych, za pomocą których prowadzona była ograniczona (pod kątem podmiotowo-przedmiotowym) ówczesna działalność gospodarcza.

Mimo pewnej przewidywalności kontraktowej, wynikającej ze specyfiki systemu gospodarki nakazowo-rozdzielczej, jej ograniczeń przedmiotowo-podmiotowych, przedsiębiorstwa te miały zapewnioną formalną możność dochodzenia swoich roszczeń na drodze quasi-sądowej, jaką zapewniało funkcjonowanie Państwowego Arbitrażu Gospodarczego.

\section{Przedsiębiorstwo państwowe jako podmiot gospodarczy w systemie gospodarki nakazowo-rozdzielczej}

Przedsiębiorstwo państwowe w pierwotnym brzmieniu, wynikającym z art. 1 ustawy z dnia 25 września 1981 roku o przedsiębiorstwach państwowych ${ }^{1}$, określane było mianem samodzielnej, samorządnej i samofinansującej podstawowej jednostki organizacyjnej gospodarki narodowej, służącej zaspokajaniu potrzeb społecznych, tworzonej w celu osiągania efektywnych ekonomicznie wyników przez produkcję dóbr, świadczenie usług lub świadczenie innej działalności.

Podmiot ten (tak jak współcześnie) wyposażony był w osobowość prawną. Również w dobie gospodarki nakazowo-rozdzielczej formalnoprawne kwestie związane z prowadzeniem jego spraw oraz reprezentacją przynależały do kompetencji organów przedsiębiorstwa² ${ }^{2}$.

Naczelny Sąd Administracyjny w Krakowie w wyroku z dnia 3 listopada 1983 roku stwierdził, że

stosownie do art. 1 ust. 1 ustawy z dnia 25 września 1981 r. o przedsiębiorstwach państwowych (Dz.U. Nr 24, poz. 122 z późn. zm.) podstawową jednostką organizacyjną gospodarki narodowej jest przedsiębiorstwo państwowe, którego dyrektor jest organem administracji gospodarczej stopnia podstawowego ${ }^{3}$.

1 Dz.U. z 1981 r. Nr 24, poz. 122 z późn. zm. Ustawa ta uchyliła dekret z 26 października 1956 roku o przedsiębiorstwach państwowych (Dz.U. z 1960 r. Nr 18, poz. 111 z późn. zm.), w którym to w art. 1 ust. 1 wskazywano, że przedsiębiorstwo państwowe jest podstawową jednostką organizacyjną gospodarki planowej, utworzoną w celu zaspokajania potrzeb społecznych w dziedzinie określonej w akcie o jego utworzeniu.

2 Zgodnie z art. 31 ustawy to ogólne zebranie pracowników (delegatów), rada pracownicza i dyrektor przedsiębiorstwa

3 Wyrok Naczelnego Sądu Administracyjnego w Krakowie z dnia 3 listopada 1983 roku, sygn. akt $\mathrm{Sa} / \mathrm{Kr}$ 856/83, ONSA 1983/2/96. 
Podobnie jak współcześnie (por. art. 2 ust. 2 ustawy) organy państwowe mogły — przynajmniej formalnie — podejmować decyzje w zakresie działalności przedsiębiorstwa państwowego tylko w wypadkach przewidzianych przepisami ustawowymi (co wyłączało ingerencję dokonywaną na podstawie innych aktów prawnych).

Jak wskazuje A. Kidyba w odniesieniu do współcześnie funkcjonujących przedsiębiorstw państwowych, ale z pewnym zachowaniem aktualności też do przedsiębiorstw okresu gospodarki centralnie planowanej:

istotną cechą przedsiębiorstw państwowych jest ich uniezależnienie od organów usytuowanych poza przedsiębiorstwami. W szczególności organy państwowe mogą podejmować decyzje w zakresie działalności przedsiębiorstwa państwowego tylko w przypadkach przewidzianych przepisami ustawowymi. Przedsiębiorstwo państwowe podejmuje decyzje we wszystkich sprawach prowadzonych przez swoje organy. Zwiększony stopień oddziaływania organów zewnętrznych na przedsiębiorstwo ma miejsce w zakresie pełnienia funkcji organów założycielskich ${ }^{4}$.

Natomiast K. Strzyczkowski wskazuje, że

istotę przedsiębiorstw państwowych jako podstawowych form organizacyjnych państwowej działalności gospodarczej wyznaczają cele i zadania, stanowiące elementy orientujące działania innych podmiotów wchodzących w stosunki z przedsiębiorstwami państwowymi. Dotyczy to szczególnie organów państwowych, które odpowiednio do celów i zadań przedsiębiorstw państwowych dokonują wyboru prawem dopuszczalnych środków wpływania na ich działalność 5 .

W systemie gospodarki centralnie planowanej przedsiębiorstwa państwowe wchodziły w skład szeroko rozumianego mienia państwowego, dlatego - co oczywiste (zarówno ze względu na samą nomenklaturę nazewniczą tychże podmiotów, jak i warunki ustrojowe, w których funkcjonowały) — ich właścicielem de facto było państwo.

Odnosząc się do tego, Sąd Najwyższy stwierdził w postanowieniu z dnia 24 października 1963 roku, że

zgodnie z wypływającą z art. 8 Konstytucji PRL zasadą jednolitego funduszu własności państwowej Państwo jest jedynym właścicielem całego mienia państwowego i zachowuje w stosunku do tego mienia pełnię uprawnień właściciela niezależnie od tego, w czyim zarządzie to mienie się znajduje, w szczególności Państwo zachowuje uprawnienia właściciela także co do mienia znajdującego się w zarządzie przedsiębiorstwa państwowego, a więc odrębnej od Skarbu Państwa osoby prawnej ${ }^{6}$.

Natomiast Z. Rybicki, dokonując wyodrębnienia istotnych elementów przedsiębiorstwa państwowego, podnosi, że

${ }^{4}$ A. Kidyba, Prawo handlowe, Warszawa 2015, s. 692.

5 K. Strzyczkowski, Prawo gospodarcze publiczne, Warszawa 2007, s. 268.

${ }^{6}$ Postanowienie Sądu Najwyższego z dnia 24 października 1963 roku, sygn. akt IIICR 252/63, OSNPG1964/3/22. 
1) przedsiębiorstwo państwowe jest jednostką organizacyjną wyposażoną w osobowość prawną,

2) przedsiębiorstwo państwowe powołane jest przez państwo do realizacji zadań gospodarczych,

3) działalność gospodarczą przedsiębiorstwo państwowe prowadzi na zasadach rozrachunku gospodarczego,

4) zatrudniony w przedsiębiorstwie państwowym personel podlega jednoosobowemu kierownictwu dyrektora,

5) przedsiębiorstwo państwowe użytkuje przekazany mu przez państwo wyodrębniony zespół środków rzeczowych ${ }^{7}$.

Co istotne, przedsiębiorstwo państwowe, oprócz tego, że kwalifikowane było jako podstawowa jednostka organizacyjna gospodarki narodowej, zaliczane było do rozbudowanego, jak na ówczesny system prawno-gospodarczy, katalogu jednostek gospodarki uspołecznionej. Jak wskazują S. Buczkowski i Z.K. Nowakowski, z punktu widzenia stosunków cywilnoprawnych (czyli po części z punktu widzenia ówczesnych stosunków gospodarczych) podstawowe znaczenie miały jednostki gospodarki uspołecznionej mające osobowość prawną. Jednostki te, jak stwierdzająautorzy, prowadziły zorganizowaną (w postaci przedsiębiorstwa) działalność gospodarczą na podstawie posiadanego przez nie tak zwanego mienia społecznego, zwanego funduszem produkcyjnym (głównym składnikiem funduszu były narzędzia pracy służące określonej produkcji $)^{8}$.

Opierając się na definicji przedsiębiorstwa państwowego $\mathrm{z}$ art. 1 powołanej ustawy, można przyjąć, że wskazany w niej cel związany z osiąganiem efektywnych ekonomicznie wyników przez produkcję dóbr, świadczenie usług lub świadczenie innej działalności można po części utożsamić ze współcześnie prowadzoną działalnością gospodarczą, na którą pod kątem podstaw regulacyjnych wskazuje między innymi ustawa z dnia 6 marca 2018 roku Prawo przedsiębiorców ${ }^{9}$.

Tożsamość ta, co oczywiste, nie może być postrzegana w sposób ścisły i wielopłaszczyznowy. Dlatego współcześnie działalność gospodarcza — zgodnie $\mathrm{z}$ art. 3 ustawy Prawo przedsiębiorców będąca zorganizowaną działalnością zarobkową wykonywaną w sposób zorganizowany i ciągły — ze względu na pewne

7 Z. Rybicki, Administracja gospodarcza w PRL, Warszawa 1975, s. 165.

8 Por. S. Buczkowski, Z.K. Nowakowski, Prawo obrotu uspołecznionego, Warszawa 1971, s. 10. Autorzy jednocześnie wskazują, że osobowość prawną w grupie jednostek gospodarki uspołecznionej miały, oprócz przedsiębiorstw państwowych, Skarb Państwa, zjednoczenia przedsiębiorstw państwowych, spółdzielnie i ich związki, kółka rolnicze i ich związki, tak zwane inne państwowe jednostki organizacyjne oraz organizacje społeczne ludu pracującego, którym przepisy szczególne przyznawały osobowość prawną. Natomiast oprócz jednostek gospodarki uspołecznionej mających osobowość prawną funkcjonowały również podmioty (zaliczone do omawianej grupy), które wprawdzie nie miały osobowości prawnej, ale ze względu na swoje wyodrębnienie (administracyjne, finansowe) mogły samodzielnie nabywać prawa i zaciągać zobowiązania i z tego tytułu miały określoną zdolność arbitrażową (na przykład zakłady budżetowe).

${ }^{9}$ Ustawa z dnia 6 marca 2018 roku Prawo przedsiębiorców (tekst jedn. Dz.U. z 2019, poz. 1292). 
odmienności ustrojowe nie może być utożsamiana $\mathrm{z}$ działalnością prowadzoną przez ówcześnie funkcjonujące przedsiębiorstwa państwowe. Przede wszystkim działalność ta - to jest prowadzona przez przedsiębiorstwa państwowe ustroju socjalistycznego przy wykorzystaniu wydzielonej na ich potrzeby części mienia ogólnonarodowego - prowadzona była wprawdzie formalnie samodzielnie, ale jednocześnie w sposób materialnie podporządkowany celom i zasadom narodowych planów społeczno-gospodarczych.

Innymi słowy przedsiębiorstwo państwowe powoływane było przez państwo, jego organy, co do zasady nie po to, by prowadziło działalność gospodarczą w znaczeniu współczesnym, lecz po to, by realizowało pewne wybrane, centralnie określone zadania, w tym o charakterze gospodarczym; zadania rzecz jasna państwa, a nie poszczególnych podmiotów tworzących wspólnie mienie państwowe. Państwa - co wypada dodać — jako swoistego, złożonego podmiotu realizującego swoje - nakreślone mocą centralnych planów — zadania społeczno-gospodarcze.

Jak podał Sąd Najwyższy w uchwale z dnia 21 marca 1983 roku:

organy administracji państwowej mogą nakładać na przedsiębiorstwa państwowe obowiązek odpłatnych świadczeń rzeczowych na cele zwalczania zagrożenia lub przerwania komunikacji na skutek zasp śnieżnych, powodzi lub usuwisk ${ }^{10}$.

W innym w wyroku, z 23 listopada 1966 roku, Sąd Najwyższy podkreślił, że

z Konstytucji PRL (art. 3 i 7) wynika podstawowy obowiązek prawny każdego obywatela — przestrzegania zasad dyscypliny gospodarczej, a w szczególności niedokonywania takich czynności, które byłyby sprzeczne z założeniami planowej polityki gospodarczej Państwa ${ }^{11}$.

Wydaje się, że słusznie (w odniesieniu do ówczesnych uwarunkowań) Z. Rybicki wskazuje, iż

przedsiębiorstwo powołane jest przez państwo dla realizacji jego zadań gospodarczych. Określenie to nie może być rozumiane zawężająco. Mówiąc o zadaniach gospodarczych, mamy na myśli realizowanie takich zadań, które służą celom wytyczonym przez państwo. Są to więc zadania gospodarcze mające określoną treść społeczną. Odpowiadają one na określone zapotrzebowanie, ustalone zgodnie z klasowymi interesami reprezentowanymi przez państwo ${ }^{12}$.

Tym samym przedsiębiorstwo państwowe okresu PRL, mimo pewnej formalnej samodzielności wynikającej z art. 1 ustawy, było podmiotem nie w pełni zadaniowo i gospodarczo samodzielnym czy też autonomicznym. Ograniczenia te - generalnie rzecz ujmując — wynikały już z samej istoty systemu ustrojowego, w ramach którego podmioty te prowadziły swoją działalność. Natomiast ich

10 Uchwała Sądu Najwyższego z dnia 21 marca 1983 roku, sygn. akt IIIAZP 1/83, OSNC 1983/10/153.

11 Wyrok Sądu Najwyższego z dnia 23 listopada 1966 roku, sygn. akt IVKR 190/66, LEX nr 168345.

12 Z. Rybicki, op. cit., s. 168. 
uszczegółowienie czy też formalnoprawna konkretyzacja znajdowała swoje oparcie i podstawę zarówno w systemie obowiązujących aktów prawa, jak i będących po części ich pochodną planów społeczno-gospodarczych.

W nawiązaniu do tego S. Grzybowski stwierdził, że „socjalistyczny charakter prawa cywilnego przejawia się w ograniczeniu autonomii woli stron, zwłaszcza j.g.u., konsekwencjami planowej gospodarki socjalistycznej"13. K. Korzan wskazał natomiast, że „samodzielność wyodrębnionych pod względem prawnym i ekonomicznym przedsiębiorstw państwowych jest czynnikiem mobilizującym do sprawnej realizacji celów odcinkowych, a tym samym celu nadrzędnego określonego w planie centralnym" 14 .

Ponadto elementem odróżniającym prowadzoną ówcześnie działalność gospodarczą od współczesnej jest niejednoznaczne zdefiniowanie zarobkowego charakteru tej działalności. Tym samym w systemie gospodarki nakazowo-rozdzielczej na uwagę zasługuje ogólna konstatacja o braku uwypuklenia - w schemacie działania - istoty zysku (działalności zarobkowej) przedsiębiorstwa państwowego.

Nie można tu mówić o pewnej konieczności czy też powinności odnoszącej się do osiągania zysku przez przedsiębiorstwa państwowe doby gospodarki nakazowo-rozdzielczej. Dlatego też ze względu na wskazane ustawowe odniesienie (odniesienie do konieczności zaspokajania potrzeb społecznych powiązanych z określonymi zadaniami państwa, również o charakterze gospodarczym) zarówno działalność zarobkowa, jak i zysk tychże podmiotów mogłyby być postrzegane jako element wtórny czy też pochodny.

Jak wskazuje J. Piotrowski:

głównym celem, jaki przyświeca przy zakładaniu przedsiębiorstwa kapitalistycznego, jest zdobycie dochodu pieniężnego. Natomiast w innych celach tworzy się przedsiębiorstwo socjalistyczne. Przedsiębiorstwo socjalistyczne zmierza do bezpośredniej realizacji zadań gospodarczych państwa. Działa ono na rachunek państwa na podstawie rozrachunku gospodarczego. Socjalistyczne przedsiębiorstwo, podobnie jak cała gospodarka socjalistyczna, ma na celu możliwe optymalne w danych warunkach zaspokojenie potrzeb społeczeństwa ${ }^{15}$.

Dodatkowo wśród różnic można wskazać formalnoprawny, jednoznaczny i obligatoryjny brak odniesienia do konieczności zaspokajania potrzeb społecznych przez współcześnie funkcjonującego przedsiębiorcę, dla którego jedna z podstaw regulacyjnych wynika z art. 4 ustawy Prawo przedsiębiorców ${ }^{16}$.

13 S. Grzybowski, System prawa cywilnego. Część ogólna, Warszawa 1974, s. 47.

14 K. Korzan, Arbitraż i postępowanie arbitrażowe, Warszawa 1980, s. 27.

15 J. Piotrowski, Ochrona praw majątkowych przedsiębiorstwa państwowego w procesie cywilnym, Warszawa 1979, s. 22.

16 Zgodnie z nim za przedsiębiorcę postrzega się osobę fizyczną, osobę prawną lub jednostkę organizacyjną niebędącą osobą prawną, której odrębna ustawa przyznaje zdolność prawną, wykonującą działalność gospodarczą. Dodatkowo za przedsiębiorców postrzega się także wspólników spółki cywilnej w zakresie wykonywanej przez nich działalności gospodarczej. 
Ponadto, co oczywiste, przedsiębiorstwa państwowe ze względu na swoje umiejscowienie w systemie gospodarki nakazowo-rozdzielczej, centralnie planowanej, funkcjonowały de facto w oderwaniu od współcześnie postrzeganej pod kątem zarówno podmiotowym (rozpatrywanym z punktu widzenia samego przedsiębiorcy), jak i przedmiotowym (z punktu widzenia określonych zasad rynkowych) - konkurencyjności, sprzecznej z ideami i zasadami systemowymi ustroju socjalistycznego PRL. Konkurencyjności, która — co warto dodać w gospodarce rynkowej powinna opierać się na dwóch podstawowych elementach — popycie i nierozerwalnie z nim związanej podaży.

W nawiązaniu do tego S. Buczkowski i Z.K. Nowakowski podkreślili, że

w socjalizmie nie ma miejsca dla całkowicie autonomicznej działalności j.g.u., gdyż oznaczałoby to panowanie w produkcji i obrocie żywiołowości i walki konkurencyjnej z tymi wszystkimi następstwami społecznymi, które byłyby zaprzeczeniem zasad i celów socjalizmu ${ }^{17}$.

Nie można zapominać również o tym, że oprócz prowadzonej działalności gospodarczej działalność przedsiębiorstwa państwowego ukierunkowana była na szeroko postrzegane zaspokojenie potrzeb społecznych (co współcześnie, co do zasady, nie jest priorytetem, a tym samym powszechnie nie występuje). Co do zasady, gdyż pewne przełożenie na powyższe można znaleźć w wynikającym $\mathrm{z}$ art. $5 \mathrm{w}$ zw. z art. 6 ustawy o przedsiębiorstwach państwowych (w brzmieniu współczesnym) podziale na przedsiębiorstwa państwowe działające na zasadach ogólnych i przedsiębiorstwa państwowe użyteczności publicznej. Podstawową rolą tych drugich podmiotów jest, czy też powinno być, bieżące i nieprzerwane zaspokajanie potrzeb ludności (w szczególności w dziedzinach związanych z produkcją lub świadczeniem usług wymienionych w art. 6 ustawy). Dlatego można mówić tu o pewnej zbieżności z koniecznością zaspokajania potrzeb społecznych przez przedsiębiorstwa państwowe doby gospodarki nakazowo-rozdzielczej (również jej końcowego okresu).

Na marginesie niniejszych rozważań można podnieść, że na gruncie sfery samorządowej odniesienie do powyższego wynika z ustawy z dnia 20 grudnia 1996 roku o gospodarce komunalnej ${ }^{18}$, w której ustawodawca zaakcentował, że gospodarka komunalna obejmuje w szczególności zadania o charakterze użyteczności publicznej, których celem jest bieżące i nieprzerwane zaspokajanie zbiorowych potrzeb ludności w drodze świadczenia usług powszechnie dostępnych (por. art. 1 ust. 2).

Warto w miejscu tym dodać, że powołana regulacja, wskazująca na podział przedsiębiorstw państwowych, obowiązywała również w pierwotnym brzmieniu ustawy. Jednakże, jak się wydaje, jej zakres i sens podmiotowo-przedmiotowy miał szersze od współczesnego znaczenie. Przyjąć bowiem należy, że obecnie

17 S. Buczkowski, Z.K. Nowakowski, op. cit., s. 15.

18 Ustawa z dnia 20 grudnia 1996 roku o gospodarce komunalnej (tekst jedn. Dz.U. z 2019 r. poz. 712 ). 
zaspokajanie potrzeb ludności jest pojęciem rodzajowo węższym od obowiązującego w systemie nakazowo-rozdzielczym terminu zaspokajania potrzeb społecznych. Pojęcie to bowiem pod kątem podmiotowym może być postrzegane jako szersze od zaspokajania potrzeb ludności, a w związku z tym zawierające w swoim zakresie kategorię praw i potrzeb niejako bezpośrednio związanych, a tym samym zaspokajanych w każdym przejawie funkcjonowania przedsiębiorstwa (przy prowadzonej przez niego działalności gospodarczej).

Jak wskazuje K. Korzan:

celem wszelkiej działalności gospodarczej jest zaspokojenie potrzeb społecznych [...]. Jednakże cel, o którym mowa, nie jest jednakowo realizowany we wszystkich ustrojach społeczno-ekonomicznych [...]. W państwach typu socjalistycznego celem bezpośrednim działalności gospodarczej jest zaspokajanie potrzeb społecznych. Osiągnięcie go warunkuje społeczna własność środków produkcji; środki produkcji będące własnością społeczną mogą być użyte tylko do zaspokojenia potrzeb ich właścicieli. Zaspokojenie tych potrzeb jest głównym i nadrzędnym celem działalności gospodarczej [...]. Można, innymi słowy, powiedzieć, że zysk w gospodarce socjalistycznej jest jedynie środkiem do osiągnięcia celu nadrzędnego, którego wykładnikiem jest maksymalne zaspokojenie potrzeb społecznych ${ }^{19}$.

W nawiązaniu do tego należy wskazać, że byt prawny przedsiębiorstw państwowych (doby gospodarki nakazowo-rozdzielczej) oraz zakres i struktura prowadzonej przez nie działalności nie były, gdyż nie mogły być ze względu na uwarunkowania ustrojowo-polityczne, wyznaczone przez jedną z podstawowych zasad gospodarki wolnorynkowej, czyli zasadę wolności gospodarczej (również pod koniec okresu jej funkcjonowania, to jest $\mathrm{w}$ drugiej połowie lat osiemdziesiątych). Teza ta znajduje uzasadnienie mimo pewnych prób wprowadzenia (przynajmniej pod kątem formalnym) pewnej liberalizacji obrotu gospodarczego, której jednym z przejawów było uchwalenie (nowatorskiej, a przy tym nowoczesnej i racjonalnej, nie tylko jak na ówczesne czasy) ustawy z dnia 23 grudnia 1988 roku o działalności gospodarczej ${ }^{20}$. Pod kątem formalnoprawnym wprowadzała ona do ówczesnego systemu prawnego, współcześnie oczywiste i akceptowalne, pojęcie zasady wolności czy też swobody działalności gospodarczej. Zgodnie z nim zarówno podejmowanie, jak i samo prowadzenie działalności gospodarczej miało być wolne i dozwolone każdemu na równych prawach, z zachowaniem warunków określonych przepisami prawa.

Ustawa ta została uchwalona w końcowym okresie funkcjonowania gospodarki nakazowo-rozdzielczej, w którym mimo pewnych symptomów czy przejawów transformacji ustrojowej w dalszym ciągu wiodącą rolę (przynajmniej pod kątem formalnoustrojowym) odgrywały jednostki gospodarki uspołecznionej (wśród których prym wiodły przedsiębiorstwa państwowe, na co wprost zdaje się wskazywać brzmienie z 1989 roku — to jest z okresu po wejściu w życie ustawy o działalności

19 K. Korzan, Arbitraż i postępowanie..., s. 14-15.

20 Ustawa z dnia 23 grudnia 1988 roku o działalności gospodarczej (Dz.U. z 1988 r. Nr 41, poz. 324 z późn. zm.). 
gospodarczej — art. 1 ustawy o przedsiębiorstwach państwowych ${ }^{21}$ ). Natomiast co istotne, ustawa ta oprócz wskazanej w art. 1 wolności gospodarczej wprowadziła w art. 7 pewną równość przedsiębiorców (równość wobec prawa) w niezmiernie istotnym zakresie (również współcześnie), to jest w zakresie szeroko postrzeganych obciążeń publicznoprawnych. Dodatkowo regulacja ta wskazywała na (nieco archaiczną współcześnie) formalną równość przedsiębiorców przy korzystaniu ze zwrotnych środków finansowania czy też współfinansowania ich działalności (za pomocą kredytów) oraz w dostępie do zaopatrzenia w środki produkcji (co obecnie można uznać za oczywisty anachronizm).

Co ciekawe, zasady te zostały wprowadzone mimo formalnej akcentacji, na mocy art. 11 Konstytucji PRL z dnia 22 lipca 1952 roku $^{22}$, socjalistycznego systemu gospodarczego, który oparty na tak zwanych uspołecznionych środkach i socjalistycznych stosunkach produkcji stanowił $\mathrm{w}$ dalszym ciągu podstawę ustroju społeczno-gospodarczego PRL. Na marginesie niniejszych rozważań można wskazać, że regulacja ta została wykreślona na mocy art. 1 pkt 7 ustawy z dnia 29 grudnia 1989 roku o zmianie Konstytucji Polskiej Rzeczypospolitej Ludowej ${ }^{23}$.

Należy podnieść, że ustawa o działalności gospodarczej, mimo ustroju socjalistycznego oraz ówczesnych warunków ustrojowo-gospodarczych, uwypukliła i zaakcentowała cel zarobkowy samej działalności gospodarczej ${ }^{24}$. Tym samym cel ten - co można uznać za nowatorskie — odnosił się również do funkcjonujących w zmieniającej się rzeczywistości gospodarczej przedsiębiorstw państwowych. Ustawa obwiązywała bowiem także w stosunku do przedsiębiorstw państwowych działających w końcowym etapie istnienia gospodarki planowanej, nakazowo-rozdzielczej.

Naczelny Sąd Administracyjny w Warszawie w wyroku z dnia 23 czerwca 1993 roku stwierdził, że

przepisy ustawy z dnia 23 grudnia 1988 r. o działalności gospodarczej mają zastosowanie do wszystkich podmiotów prowadzących działalność gospodarczą, o jakiej mowa w art. 2 ust. 1 tej ustawy, i to niezależnie od czasu ich powstania i prawnej formuły organizacyjnej ${ }^{25}$.

${ }^{21}$ Pojęcie przedsiębiorstwa państwowego zostało zmienione w marcu 1990 roku, to jest po transformacji ustrojowej. Zgodnie ze zmienionym brzmieniem art. 1 ustawy o przedsiębiorstwach państwowych przedsiębiorstwo to określono mianem samodzielnego, samorządnego i samofinansującego się podmiotu gospodarczego mającego osobowość prawną. W okresie tym usunięto również między innymi art. 2 ustawy, traktujący, że przedsiębiorstwo państwowe, gospodarując wydzieloną częścią mienia ogólnonarodowego, prowadzi samodzielnie działalność gospodarczą zgodnie z celami narodowego planu społeczno-gospodarczego.

22 Konstytucja PRL z dnia 22 lipca 1952 roku (Dz.U. z 1976 r. Nr 7, poz. 36 z późn. zm.).

23 Ustawa z dnia 29 grudnia 1989 roku o zmianie Konstytucji Polskiej Rzeczypospolitej Ludowej (Dz.U. z 1989 r. Nr 75, poz. 444).

24 Art. 2 tego aktu prawnego wskazywał, że działalnością gospodarczą, w rozumieniu ustawy, jest działalność wytwórcza, budowlana, handlowa i usługowa, prowadzona w celach zarobkowych i na własny rachunek podmiotu prowadzącego taką działalność.

25 Wyrok Naczelnego Sądu Administracyjnego z dnia 23 czerwca 1993 roku, sygn. akt III SA 850/92, LEX nr 10866. 


\section{Państwowy Arbitraż Gospodarczy jako organ rozstrzygania sporów gospodarczych zachodzących między przedsiębiorstwami państwowymi}

W systemie gospodarki nakazowo-rozdzielczej prawo do sądu jednostek gospodarki uspołecznionej, w tym przedsiębiorstw państwowych, było prawem o charakterze ograniczonym.

Szeroko postrzegane sprawy o charakterze gospodarczym poddawane były bowiem pod rozstrzygnięcie podmiotu o charakterze i strukturze pozasądowej, to jest Państwowego Arbitrażu Gospodarczego, który w końcowym systemie gospodarki centralnie planowanej funkcjonował na podstawie regulacji wynikających z ustawy z dnia 23 października 1975 roku o Państwowym Arbitrażu Gospodarczym $^{26}$. Ustawa ta zastąpiła obowiązujący dotychczas dekret $\mathrm{z}$ dnia 5 sierpnia 1949 roku o Państwowym Arbitrażu Gospodarczym ${ }^{27}$.

Jak wskazuje M. Tyczka w odniesieniu do idei powstania pozasądowego arbitrażu gospodarczego:

powstanie arbitrażu gospodarczego związane jest z powstaniem planowej centralnie zarządzanej gospodarki socjalistycznej. Upaństwowienie podstawowych środków produkcji, ich rozbudowa oraz równoległa rozbudowa innych społecznych form gospodarowania spowodowały, że przeważająca część działalności gospodarczej skupiła się w rękach Państwa, spółdzielni i innych organizacji społecznych ${ }^{28}$.

Tym samym w PRL, podobnie jak i po części w innych państwach o ustroju socjalistycznym, spory o charakterze gospodarczym zachodzące między jednostkami gospodarki uspołecznionej niejako wyłączono spod kompetencji sądów powszechnych, poddając je tym samym pod rozstrzygnięcia organu pozasądowego, jakim niewątpliwie był Państwowy Arbitraż Gospodarczy.

Zgodnie bowiem z regulacją wynikającą z art. 2 wskazanej ustawy spory zachodzące między przedsiębiorstwami państwowymi i dotyczące spraw: o charakterze majątkowym, o zawarcie lub ustalenie treści umowy, o zmianę lub rozwiązanie umowy, o ustalenie stosunku prawnego lub prawa miały być poddane pod rozstrzygnięcie Państwowego Arbitrażu Gospodarczego.

Można zatem przyjąć, że powyższa regulacja de facto potwierdziła monopol czy też quasi-monopol Państwowego Arbitrażu Gospodarczego na rozstrzyganie sporów o szeroko rozumianym charakterze gospodarczym, których stronami były podstawowe jednostki gospodarki uspołecznionej - przedsiębiorstwa państwowe, mające - na mocy art. 3 ustawy - określoną zdolność arbitrażową, którą

26 Ustawa z dnia 23 października 1975 roku o Państwowym Arbitrażu Gospodarczym (Dz.U. z 1975 r. Nr 34, poz. 183 z późn. zm.).

27 Dekret z dnia 5 sierpnia 1949 roku o Państwowym Arbitrażu Gospodarczym (Dz.U. z 1961 r. Nr 37, poz. 195 z późn. zm.).

28 M. Tyczka, Arbitraż i postępowanie arbitrażowe, Warszawa 1985, s. 11. 
można w pewien sposób utożsamiać czy też porównywać ze zdolnością sądową, to jest możnością występowania $\mathrm{w}$ postępowaniu prowadzonym przed sądem w charakterze strony.

Jak wskazuje A. Rosienkiewicz:

każdy podmiot uspołeczniony, ażeby występować w charakterze strony w postępowaniu arbitrażowym musi posiadać zdolność arbitrażową, zdolność procesową oraz legitymację procesową. Dwa pierwsze atrybuty mają charakter procesowy — trzeci materialnoprawny. Zdolność arbitrażowa jest pojęciem równorzędnym z pojęciem zdolności sądowej. Ta ostatnia ma tak podstawowe znaczenie, że zdolność arbitrażowa uznana być może za swoistą przesłankę procesową ${ }^{29}$.

Dlatego wydaje się, że przedsiębiorstwa państwowe jako podstawowe formy organizacyjne prowadzonej ówcześnie działalności, oprócz wskazanej zdolności arbitrażowej, ze względu na swój zakres działania, a tym samym przypisaną im kategorię spraw, były podmiotami o de facto najbardziej rozwiniętym czy też rozbudowanym pod kątem podmiotowo-przedmiotowym interesie prawnym związanym z możnością dochodzenia roszczeń na drodze postępowania arbitrażowego.

Główna Komisja Arbitrażowa w orzeczeniu z dnia 13 stycznia 1984 roku stwierdziła, że

interes prawny powoda stanowi konieczną przesłankę skuteczności dochodzenia na drodze postępowania arbitrażowego ustalenia istnienia stosunku prawnego lub prawa. Interes prawny uzasadniający dochodzenie takiego ustalenia nie istnieje wówczas, gdy w konkretnej sytuacji po stronie żądającego możliwe jest wniesienie wniosku o świadczenie ${ }^{30}$.

Wydaje się natomiast, że wskazane wyłączenie (dotyczące rozstrzygania przez sądy powszechne spraw gospodarczych między przedsiębiorstwami państwowymi) ściśle można powiązać z ówczesną rolą jednostek gospodarki uspołecznionej, w tym przedsiębiorstw państwowych, w systemie gospodarki planowanej, uwarunkowaniami politycznymi i powiązanymi z nimi, czy też wynikającymi z nich uwarunkowaniami gospodarczymi.

Dodatkowo można, jak się wydaje, wskazać tu pewną odmienność zadań (a tym samym kompetencji) realizowanych i wypełnianych w systemie socjalistycznym przez sądy powszechne i Państwowe Komisje Arbitrażowe.

Jak bowiem wskazuje A. Rosienkiewicz:

sądy w państwie ludowym, rozstrzygając spory, wymierzają sprawiedliwość. Organ rozstrzygający spory pomiędzy jednostkami gospodarki uspołecznionej natomiast musi dbać głównie o umocnienie socjalistycznego systemu gospodarowania. System ten zaś, jak wiemy, opiera się na planowej działalności przedsiębiorstw państwowych i spółdzielczych, działających

29 A. Rosienkiewicz, Postępowanie przed Państwowymi Komisjami Arbitrażowymi, Wrocław 1975 , s. $54-55$.

${ }^{30}$ Orzeczenie Głównej Komisji Arbitrażowej z dnia 13 stycznia 1984 roku, sygn. akt IP10165/83, OSP 1985/1/18. 
samodzielnie na zasadach rozrachunku gospodarczego, tj. tymi elementami, które stanowią podstawę organizacji gospodarki uspołecznionej ${ }^{31}$.

Wskazane odmienności warunkują również pewną odmienność celów rozstrzygania. Wydaje się bowiem, że Państwowy Arbitraż Gospodarczy przez swoje rozstrzygnięcia miał, oprócz niejako bieżącego rozwiązania sporu, umożliwiać w miarę bezkonfliktowe funkcjonowanie jednostek gospodarki uspołecznionej, między innymi po to, by nałożone odgórnie na te podmioty plany gospodarcze mogły być przez nie, w systemie powiazań kooperacyjnych, w miarę sprawnie — biorąc pod uwagę powszechne niedobory gospodarki okresu końcowego PRL - realizowane.

\section{W odniesieniu do tego A. Rosienkiewicz podkreślił:}

między innymi [...] wskazuje się też na to, że funkcją sądów powszechnych, które rozstrzygają konflikty za pomocą prawa, jest jedynie ustosunkowanie się do zaszłości, jaka miała miejsce w przeszłości, celem rozstrzygnięcia sporu gospodarczego natomiast jest usunięcie przeszkody do dalszej bezkonfliktowej współpracy pomiędzy stronami w przyszłości ${ }^{32}$.

Można przyjąć, że teza ta znajduje racjonalne uzasadnienie w odniesieniu do przedsiębiorstw państwowych, to jest podmiotów, na których w głównej mierze spoczywał obowiązek realizacyjny planów gospodarczych PRL; podmiotów, za pomocą których realizowano, czy też starano się realizować, ówczesne zadania gospodarcze państwa.

Jak wskazuje M. Tyczka:

wśród jednostek państwowych w postępowaniu arbitrażowym szczególna rola przypada przedsiębiorstwom państwowym, jako podstawowym ogniwom organizacyjnym gospodarki socjalistycznej. Znaczenie przedsiębiorstw państwowych jako stron w postępowaniu arbitrażowym wynika z tego, że w olbrzymiej większości spraw występują one w charakterze stron oraz że właśnie w nich koncentruje się gospodarcza działalność Państwa ${ }^{33}$.

Dlatego też, co istotne, prawomocne ${ }^{34}$ rozstrzygnięcia Państwowego Arbitrażu Gospodarczego oprócz stron postępowania miały moc wiążącą również w stosunku do jego organów, a także innych instytucji i organów państwowych oraz organizacji spółdzielczych i społecznych ówczesnego systemu prawno-gospodarczego.

Sąd Najwyższy w wyroku z dnia 20 czerwca 1980 roku wskazywał, że

31 A. Rosienkiewicz, Zapobieganie i rozwiąywanie sporów pomiędzy jednostkami uspołecznionymi, Wrocław 1978, s. 38.

32 A. Rosienkiewicz, Zapobieganie i rozwiązywanie sporów..., s. 39.

33 M. Tyczka, op. cit., s. 122.

34 Prawomocne, czyli w stosunku do którego, zgodnie z art. 35 ust. 2 ustawy, nie przysługiwał środek odwoławczy. Natomiast środkami odwoławczymi od orzeczeń okręgowej komisji arbitrażowej (Państwowy Arbitraż Gospodarczy — por. art. 7 — wykonywał swoje zadania poprzez Główną Komisję Arbitrażową oraz okręgowe komisje arbitrażowe) były, zgodnie z art. 32 ust. 1 pkt 1, odwołania. 
prawomocne orzeczenia Państwowego Arbitrażu Gospodarczego wiążą strony, organy Państwowego Arbitrażu Gospodarczego i inne organy państwowe (art. 35 ust. 1 ustawy z dnia 23 października 1975 r. o Państwowym Arbitrażu Gospodarczym — Dz.U. Nr 34, poz. 183). Pod względem przedmiotowym jednak ich moc sprowadza się tylko do tego, co w związku z podstawą sporu stanowiło przedmiot rozstrzygnięcia ( $\$ 20$ pkt 2 rozporządzenia Rady Ministrów z dnia 21 listopada 1975 r. w sprawie postępowania arbitrażowego - Dz.U. Nr 39, poz. 209). Ustalenia faktyczne uzasadnienia stanowią zaś nie przedmiot, lecz powody rozstrzygnięcia zawartego w sentencji orzeczenia arbitrażowego. Tymi ustaleniami więc sąd — zwłaszcza w sprawie, w której jedna ze stron nie brała udziału w postępowaniu arbitrażowym — nie jest związany ${ }^{35}$.

System rozstrzygania sporów gospodarczych — bazujący na regulacjach ustawy z 1975 roku o Państwowym Arbitrażu Gospodarczym, zachodzących między przedsiębiorstwami państwowymi - funkcjonował do 1989 roku. W tym roku bowiem uchwalono ustawę z dnia 24 maja 1989 roku o rozpoznawaniu przez sądy spraw gospodarczych ${ }^{36}$. Jej mocą niejako uchylono kompetencje Państwowego Arbitrażu Gospodarczego jako organu rozstrzygającego spory gospodarcze między przedsiębiorstwami państwowymi. Regulacja uchyliła ustawę o Państwowym Arbitrażu Gospodarczym, przekazując jednocześnie pod wyłączne kompetencje orzecznicze sądów powszechnych rozstrzyganie spraw o charakterze gospodarczym (por. art. 8).

Tym samym ustawa zlikwidowała, po blisko 40 latach (biorąc pod uwage dekret z 1949 roku), funkcjonowanie w dziedzinie szeroko rozumianych sporów gospodarczych organu pozasądowego charakterystycznego dla ustroju PRL oraz ustrojów części państw socjalistycznych ${ }^{37}$ ówczesnego systemu i porządku prawnoustrojowego państw Europy Wschodniej.

\section{Wnioski}

Funkcjonowanie w ustroju socjalistycznym zarówno ówczesnych przedsiębiorstw państwowych, jak i Państwowego Arbitrażu Gospodarczego można uznać za pewną specyfikę gospodarki nakazowo-rozdzielczej, ściśle związaną zarówno z obowiązującym systemem politycznoprawnym, jak i wynikającym z niego systemem gospodarczym, opierającym się — pod kątem produkcji i świadczenia usług — na rozbudowanym katalogu jednostek gospodarki uspołecznionej.

35 Wyrok Sądu Najwyższego z dnia 20 czerwca 1980 roku, sygn. akt II CR 173/80, OSNC 1981/2-3/33.

36 Ustawa z dnia 24 maja 1989 roku o rozpoznawaniu przez sądy spraw gospodarczych (tekst jedn. Dz.U. z 2016 r. poz. 723).

37 Przykładowo A. Rosienkiewicz wskazuje, że arbitraż gospodarczy funkcjonował między innymi w ZSRR, ówczesnej Rumunii, Bułgarii oraz Czechosłowacji — por. idem, Zapobieganie i rozwiązywanie sporów..., s. 34 . 
Mimo pewnego planowania — zarówno zadań, działań, jak i środków realizacyjnych — system ten nie był wolny od określonych sporów zachodzących również między jednostkami gospodarki uspołecznionej, w tym między przedsiębiorstwami państwowymi. Dlatego też do ich rozwiązywania oraz zapobiegania im w przyszłości został powołany Państwowy Arbitraż Gospodarczy, który na drodze pozasądowej w głównej mierze zmonopolizował zakres podmiotowo-przedmiotowy spraw gospodarczych rozstrzyganych w ówczesnych realiach prawnych.

\section{Bibliografia}

\section{Literatura}

Buczkowski S., Nowakowski Z.K., Prawo obrotu uspołecznionego, Warszawa 1971.

Grzybowski S., System prawa cywilnego. Część ogólna, Warszawa 1974.

Kidyba A., Prawo handlowe, Warszawa 2015.

Korzan K., Arbitraż i postępowanie arbitrażowe, Warszawa 1980.

Piotrowski J., Ochrona praw majątkowych przedsiębiorstwa państwowego w procesie cywilnym, Warszawa 1979.

Rosienkiewicz A., Postępowanie przed Państwowymi Komisjami Arbitrażowymi, Wrocław 1975.

Rosienkiewicz A., Zapobieganie i rozwiąywanie sporów pomiędzy jednostkami uspołecznionymi, Wrocław 1978.

Rybicki Z., Administracja gospodarcza w PRL, Warszawa 1975.

Strzyczkowski K., Prawo gospodarcze publiczne, Warszawa 2007.

Tyczka M., Arbitraż i postepowanie arbitrażowe, Warszawa 1985.

\section{Orzecznictwo}

Postanowienie Sądu Najwyższego z dnia 24 października 1963 roku, sygn. akt IIICR 252/63, OSNPG 1964/3/22.

Uchwała Sądu Najwyższego z dnia 21 marca 1983 roku, sygn. akt IIIAZP 1/83, OSNC 1983/10/153. Wyrok Naczelnego Sądu Administracyjnego w Krakowie z dnia 3 listopada 1983 roku, sygn. akt Sa/ Kr 856/83, OSNA 1983/2/96.

Wyrok Naczelnego Sądu Administracyjnego w Warszawie z dnia 23 czerwca 1993 roku, sygn. akt IIISA 850/92, LEX nr 10866.

Wyrok Sądu Najwyższego z dnia 23 listopada 1966 roku, sygn. akt IVKR 190/66, LEX nr 168345. Wyrok Sądu Najwyższego z dnia 20 czerwca 1980 roku, sygn. akt IICR 173/80, OSNC 1981/2-3/22.

\section{Orzecznictwo arbitrażowe}

Orzeczenie Głównej Komisji Arbitrażowej z dnia 13 stycznia 1984 roku, sygn. akt IP-10165/83, OSP 1985/1/18. 


\section{Akty prawne*}

Dekret z dnia 5 sierpnia 1949 roku o Państwowym Arbitrażu Gospodarczym (Dz.U. z 1961 r. Nr 37, poz. 195 z późn. zm.).

Dekret z dnia 26 października 1956 roku o przedsiębiorstwach państwowych (Dz.U. z 1960 r. Nr 18, poz. 111 z późn. zm.).

Konstytucja PRL z 22 lipca 1952 roku (Dz.U. z 1976 r. Nr 7, poz. 36 z późn. zm.).

Ustawa z dnia 23 października 1975 roku o Państwowym Arbitrażu Gospodarczym (Dz.U. z 1975 r. Nr 34, poz. 183 z późn. zm.).

Ustawa z dnia 25 września 1981 roku o przedsiębiorstwach państwowych (Dz.U. z 1981 r. Nr 24, poz. $122 \mathrm{z}$ późn. zm.).

Ustawa z dnia 23 grudnia 1988 roku o działalności gospodarczej (Dz.U. z 1988 r. Nr 41, poz. 324 z późn. zm.).

Ustawa z dnia 24 maja 1989 roku o rozpoznawaniu przez sądy spraw gospodarczych (Dz.U. z 2016 r. poz. 723).

Ustawa z dnia 29 grudnia 1989 roku o zmianie Konstytucji Polskiej Rzeczypospolitej Ludowej (Dz.U. z 1989 r. Nr 75, poz. 444).

Ustawa z dnia 20 grudnia 1996 roku o gospodarce komunalnej (tekst jedn. Dz.U. z 2019 r. poz. 712).

Ustawa z dnia 6 marca 2018 roku Prawo przedsiębiorców (tekst jedn. Dz.U. z 2019 r, poz. 1292).

* W bibliografii podano publikatory z dnia wejścia w życie danego aktu prawnego. 